\title{
Re: Autism Spectrum Disorders are not Linked to $\beta 2$ Adrenergic Receptor Agonists Treatment for Preterm Labour/Asthma - Still should be Administered $<72 \mathrm{~h}$
}

Reichmann JP*

1322 Garrick Way, Marietta, 30068 Ga, USA

Corresponding author: James P Reichmann, 1322 Garrick Way, Marietta, 30068 Ga, USA, Tel: 404780 5555; E-mail: reichmannjim@gmail.com

Received date: March 7, 2017; Accepted date: March 9, 2017; Published date: March 14, 2017

Copyright: (C) 2017 Reichmann JP. This is an open-access article distributed under the terms of the Creative Commons Attribution License, which permits unrestricted use, distribution and reproduction in any medium, provided the original author and source are credited.

Citation: Reichmann JP (2017) Re: Autism Spectrum Disorders are not Linked to $\beta 2$ Adrenergic Receptor Agonists Treatment for Preterm Labour/Asthma - Still should be Administered <72 h. J Clin Med Genomics 5: 146. doi: 10.4172/2472-128X.1000146

\section{Letter to Editor}

\section{Dear Editor:}

I read with great interest the commentary authored by Dr. Morrison and Dr. Elliott entitled, "Autism Spectrum Disorders are not linked to $\beta$-2 Adrenergic Receptor Agonists Treatment for Preterm Labour/ Asthma [1]. The same authors have written narrative opinion pieces regarding the association between terbutaline and autism spectrum disorders [2-4]. Letters to the editor have refuted the strength of their assertion $[5,6]$. Interestingly this argument is largely academic because the US Food and Drug Administration (FDA) has already determined that long term exposure $(>72 \mathrm{~h})$ is unsafe for the mother and as a result terbutaline has received a "black box warning" stating it is unsafe to administer to pregnant women as a maintenance therapy for preterm labour [7]. In that same correspondence to this author the FDA stated, "it is not possible to draw conclusions regarding an association between terbutaline exposure in utero and autism" given the limitations of the evidence. The evidence neither proves nor disproves a relationship. A review article on the topic presented a case for biological plausibility of an association between terbutaline exposure in utero and autism spectrum disorders and a recommendation that treatment duration should be as short as clinically feasible; that seems reasonable [8].

\section{References}

1. Morrison JC, Elliott JP (2016) Autism spectrum disorders are not linked to $\beta$-2-adrenergic receptor agonists treatment for preterm labour/asthma. J Clin Med Gen 4: 144.

2. Elliott JP, Morrison JC (2013) The evidence regarding maintenance tocolysis. Obstet Gynaecol 2013: 1-11.

3. Elliott JP, Morrison JC (2013) Terbutaline and other beta-agonist drugs do not cause autism spectrum disorders. OA Autism 1: 16

4. Elliott JP, Morrison JC (2015) Autism is not caused by terbutaline. AutismOpen Access 5: 139.

5. Reichmann JP (2014) Letter to the editor re: Elliott and Morrison article on terbutaline and other beta-agonist and autism spectrum disorder. OA Autism 2: 17.

6. Singh K, Ansari MT, Gaudet LM (2014) Letter to the editor: Subcutaneous terbutaline pump for maintenance of tocolysis following arrest 2014: 1-2. 